\title{
Riparian Quality Index (RQI): A methodology for characterising and assessing the environmental conditions of riparian zones
}

\author{
Marta González del Tánago* and Diego García de Jalón \\ E.T.S. Ingenieros de Montes, Universidad Politécnica de Madrid, Ciudad Universitaria, 28040 Madrid. \\ *Corresponding author: marta.gtanago@upm.es
}

Received: 22/3/2010 Accepted: 4/12/2010

\begin{abstract}
Riparian Quality Index (RQI): A methodology for characterising and assessing the environmental conditions of riparian zones

This paper presents a new version of the Riparian Quality Index (RQI). This index serves to assess the ecological status of riparian systems. The paper provides recommended field forms for the collection of the data used to characterise riparian systems prior to their assessment. The RQI considers the main sources of riparian ecological functions and environmental services. It represents a useful tool for monitoring and evaluating the structure of riparian zones, an element of the river morphological conditions considered by the Water Framework Directive. The Index was applied to the Guadiana Basin and other Spanish rivers providing helpful criteria for not only evaluating the present status of riparian systems but also formulating diagnosis and rehabilitation options. It represents a checklist of riparian natural characteristics and possible human-impacted riparian features, and it has valuable potential applications for post-project appraisals.
\end{abstract}

Key words: Riparian systems, environmental assessment, RQI, physical habitat evaluation, Water Framework Directive, river restoration.

\section{RESUMEN}

Índice de Calidad Riparia (RQI): Una mateodología para caracterizar y valorar las condiciones ambientales de las zonas riparias

En este trabajo se presenta una nueva versión del índice RQI, conjuntamente con una propuesta de estadillos de campo para la toma de datos y la caracterización de las riberas, que debe ser previa a la interpretación y valoración de su estado. Esta nueva versión del RQI considera los principales componentes de las riberas de los ríos que desarrollan las funciones ecológicas y los servicios ambientales de los corredores fluviales, y representa una herramienta útil para el control y seguimiento de la estructura riparia, la cual forma parte de las condiciones morfológicas de los ríos consideradas por la Directiva Marco del Agua. El índice ha sido aplicado en la Cuenca del Guadiana y en otras regiones españolas, suministrando criterios útiles no solo para la evaluación del estado ecológico de las riberas, sino también para la formulación de diagnosis y opciones de rehabilitación o restauración, representando una lista de características naturales y posibles impactos derivados de actividades humanas de las zonas riparias, con un uso potencial para la evaluación post-proyecto.

Palabras clave: Riberas fluviales, valoración ambiental, RQI, evaluación del hábitat físico, Directiva Marco del Agua, restauración de ríos.

\section{INTRODUCTION}

The study of riparian systems is of great scientific interest. The riparian habitat supports the sur- rounding fluvial ecosystem throughout its entire length and integrates many interactions between the aquatic and terrestrial components of the landscape. It is therefore crucial to the preserva- 
tion of river biodiversity (Ward, 1989; Ward et al., 2002; Naiman et al., 2005; Corenblit et al., 2007).

Riparian systems also represent a vital component of river management because their state affects many river-related environmental services. Because of their spatial position and connectivity with flowing water channels, riparian systems are flooded periodically and play an important role in water infiltration and aquifer recharge. Moreover, they provide flood attenuation and serve to decrease hydrological risks (Horn \& Richards, 2006). As an important landform agent and flow resistance factor, riparian vegetation is responsible for the majority of energy losses in fluvial systems. Roots increase substrate cohesion, and stems and leaves modify bed roughness, thereby controlling sediment erosion, transport and deposition, both in the channel and in the floodplain (Gurnell \& Petts, 2002; 2006; Corenblit et al. 2008; 2009). Several processes for the exchange of matter and energy with the river channel occur in the riparian zone. This habitat serves to protect in-stream water quality by acting as a sink and filter of sediment and nutrients (Tabachi et al. 2000; Naiman et al., 2005; Burt et al., 2006). Moreover, riparian forests represent important natural corridors in the landscape (Schnitzler-Lenoble, 2007) and constitute areas of high biodiversity. These forested corridors have great value as the site of recreation and cultural events.

The importance of riparian zones in the ecological functioning of river systems has been widely recognised in recent European policies. Thus, the Water Frame Work Directive (OJEC, 2000) includes the structure of the riparian zone in the morphological conditions that, together with the hydrological regime and river continuity, represent the main hydromorphological elements supporting the biological communities. The Directive recommends that the structure of riparian zones should be analysed systematically and that their restoration and conservation should be included within the programmes of measures that form part of the Integrated Basin Management Plans. Moreover, two additional recent European Directives highlight the existing interest in monitoring and restoring riparian and flood-prone ar- eas. The Floods Directive (OJEU, 2007) seeks to prevent damage and hydrological risk, and the Pesticides Directive (OJEU, 2009) aims to minimise the risk of off-site pollution.

Mainly as a consequence of the requirements of the European Directives cited above, there is great interest in practical environmental assessment methods that address the structure and functionality of riparian zones. With the aid of these methods, the needed assessment and monitoring tasks may be easily performed. These methods should support the periodic surveillance and diagnosis of riparian status, and they should help to formulate restoration activities that include fluvial processes serving to mitigate alterations resulting from human activities. These methods should also be useful for post-project appraisals intended to detect ecological trajectories of recovery or degradation following interventions or management changes.

Several methods have been proposed to evaluate the riparian conditions of rivers. Some of these methods give special emphasis to vegetation structure (Munné et al., 1998; Munné et al., 2003; Winward, 2000), whereas others are based more on riparian dimensions, habitat quality and land use (Petersen, 1992; Bjorkland et al., 2001; Ward et al., 2003; Jansen et al., 2004; González del Tánago et al., 2006). Other river assessment methods also use some riparian characteristics to assess the status of the physical habitat according to different objectives. Several of these methods deserve particular mention: the protocols of Raven et al. (1997) and Pardo et al. (2002) to characterise and classify rivers; the methods proposed by Barbour et al. (2002), Ladson \& White (1999), and Simpson \& Norris (2000) to link physical features with biota and to determine the ability of the aquatic habitat to support optimal biological conditions; the approach of Brierley et al. (2002) to describe river behaviour and to predict river character and responses to disturbance; the proposal of Davies et al. (2000) to estimate the ecological condition of the instream habitat and predict the probability of occurrence of each habitat feature at certain sites; and the methodology of Ollero et al. (2008) to assess the hydromorphological status of rivers. A revised 
version of the Ollero et al. (2008) methodology is included in this volume (Ollero et al. 2011).

In this paper, a more up-to-date version of the RQI methodology proposed by González del Tánago et al. (2006) is presented, together with additional new data-collection forms.

The RQI represents a quick and standardised survey method that is relatively easy to apply in the field to gather quantitative information on the structure of riparian zones for assessing their ecological status. The method has potential applications to monitoring and diagnosis, to rehabilitation or restoration design, to setting conservation priorities and to post-project evaluation.

The initial version of RQI methodology only described the scoring system used to assess riparian conditions but did not include protocols for previous riparian characterisation. This new version of RQI recognises that it is of great interest to store the quantitative information that has been collected in the field and that will subsequently be encapsulated by scoring systems.
Accordingly, the new version of RQI includes field forms that serve to standardise the collection and storage of riparian data and thereby to facilitate the creation of databases for future analysis. The variables proposed for riparian characterisation can be used for riparian monitoring and riparian recovery or degradation evaluation. They can therefore be used as needed to achieve different purposes. With this new approach, riparian systems are first characterised according to their hydromorphological and ecological conditions. They are then assessed and scored by comparing their actual status with an appropriate potential or reference status based on valley and river types.

The previous application of the first version of RQI to several different rivers produced some misleading statements and interpretations. Longitudinal continuity and the assessment of bank conditions proved to be of particular concern. In this new version of RQI, important refinements have been added to address these two ri-

Table 1. RQI Scores for assessing width dimension status of riparian zones. Puntuaciones del RQI para evaluar el estado de la anchura de la zona riparia.

\section{DIMENSIONS OF LAND WITH RIPARIAN VEGETATION (AVERAGE WIDTH OF RIPARIAN CORRIDOR)}

Assess each margin separately. Identify the band containing riparian species (any species which presence is related to the river) and estimate its average width along the study reach. Look for restrictions to riparian corridor width due to human influence. If they do not exist, any width would be considered very good status. Take into account that riparian dimensions can be naturally reduced in confined valleys due soil constraints or the adjacent slopes.

\begin{tabular}{|c|c|c|c|c|c|c|c|c|c|c|c|c|c|c|}
\hline \multicolumn{3}{|c|}{ Very good } & \multicolumn{3}{|c|}{ Good } & \multicolumn{3}{|c|}{ Moderate } & \multicolumn{3}{|c|}{ Poor } & \multicolumn{3}{|c|}{ Bad } \\
\hline \multicolumn{3}{|c|}{$\begin{array}{l}\text { No restrictions to } \\
\text { riparian vegetation } \\
\text { development and } \\
\text { extension across the } \\
\text { valley due to human } \\
\text { influence. } \\
\text { Riparian vegetation is } \\
\text { connecting with upland } \\
\text { species, and covers all } \\
\text { land between channel } \\
\text { and adjacent slopes. }\end{array}$} & \multicolumn{3}{|c|}{$\begin{array}{l}\text { Average width of } \\
\text { Riparian corridor } \\
\text { slightly restricted by } \\
\text { human action. In } \\
\text { unconfined valleys, } \\
\text { average width more } \\
\text { than } 3 \text { active channel } \\
\text { widths, or exceeding } \\
60 \text { m. In } \\
\text { morphologically } \\
\text { confined valleys, } \\
\text { reductions in riparian } \\
\text { width affect less than } \\
30 \% \text { of riparian length. }\end{array}$} & \multicolumn{3}{|c|}{$\begin{array}{l}\text { Average width of } \\
\text { Riparian corridor } \\
\text { moderately restricted } \\
\text { by human action. } \\
\text { In unconfined valleys, } \\
\text { average width between } \\
3 \text { and } 1 \text { active channel } \\
\text { widths, or exceeding } \\
30 \mathrm{~m} \text {. In confined } \\
\text { valleys, reduction in } \\
\text { riparian width affect } \\
\text { between } 30 \text { and } 60 \% \\
\text { of riparian length. }\end{array}$} & \multicolumn{3}{|c|}{$\begin{array}{l}\text { Average width of } \\
\text { Riparian corridor } \\
\text { significantly reduced by } \\
\text { human action. } \\
\text { In unconfined valleys, } \\
\text { average width less than } \\
1 \text { active channel width. } \\
\text { In confined valleys, } \\
\text { reduction in riparian } \\
\text { width affects more than } \\
60 \% \text { or riparian length. }\end{array}$} & \multicolumn{3}{|c|}{$\begin{array}{l}\text { Average width of } \\
\text { Riparian corridor } \\
\text { severely reduced, or } \\
\text { non-existent due to } \\
\text { human actions. } \\
\text { Channel banks } \\
\text { connected to } \\
\text { agricultural fields, } \\
\text { urbanized areas or } \\
\text { roads. } \\
\text { Consider } 0 \text { score when } \\
\text { the channel is laterally } \\
\text { limited and connects } \\
\text { with paved areas where } \\
\text { riparian vegetation } \\
\text { cannot grow. }\end{array}$} \\
\hline 15 & 14 & 13 & 12 & 11 & 10 & 9 & 8 & 7 & 6 & 5 & 4 & 3 & 2 & 1 \\
\hline
\end{tabular}


parian attributes. Moreover, some simplifications in the assessment of vegetation structure have been made to facilitate field analysis, and the as- sessment of the presence of large woody debris on banks and floodplains has been added as an indicator of river naturalness and lateral connectivity.

Table 2. RQI Scores for assessing longitudinal continuity, coverage and distribution pattern of riparian corridors. Puntuaciones del RQI para evaluar la continuidad longitudinal, la cobertura y el patrón de distribución del corredor ripario.

\section{LONGITUDINAL CONTINUITY, COVERAGE AND DISTRIBUTION PATTERN OF RIPARIAN CORRIDOR (WOODY VEGETATION)}

Assess each margin separately, referred to the riparian vegetated area. Estimate longitudinal continuity and coverage based on distribution pattern of woody vegetation associations. Estimate intensity of fragmentation based on size and frequency of open areas created by human action, and land-use within these areas compromising corridor functions.

In natural conditions, different succession stages of riparian vegetation linked to floods variability and fluvial forms can be observed, resulting in a high heterogeneity of vegetation forms and floodplain geomorphic units, with open gravel and sand areas corresponding to "very good" status (Corenblit et al. 2009). Score the intensity of human intervention determining: a gradually lost of this heterogeneity linked to the continuous interaction between floods, sediments and vegetation; a decrease of natural continuity and coverage promoting fragmentation; or, by the contrary, an increase of mature forest continuity and coverage with homogeneous distribution pattern due to flow regulation and flood control.

\begin{tabular}{|c|c|c|c|c|c|c|c|c|c|c|c|c|c|c|}
\hline \multicolumn{3}{|c|}{ Very good } & \multicolumn{3}{|c|}{ Good } & \multicolumn{3}{|c|}{ Moderate } & \multicolumn{3}{|c|}{ Poor } & \multicolumn{3}{|c|}{ Bad } \\
\hline \multicolumn{3}{|c|}{$\begin{array}{l}\text { Continuity and } \\
\text { Coverage of riparian } \\
\text { corridor in natural } \\
\text { condition. } \\
\text { Usually, different } \\
\text { vegetation strata cover } \\
\text { the full length of the } \\
\text { segment, showing a } \\
\text { heterogeneous pattern } \\
\text { linked to natural fluvial } \\
\text { forms and flood } \\
\text { dynamics, without } \\
\text { alterations related to } \\
\text { human actions. }\end{array}$} & \multicolumn{3}{|c|}{$\begin{array}{l}\text { Riparian corridor } \\
\text { slightly cleared or } \\
\text { fragmented by human } \\
\text { intervention, or slightly } \\
\text { induced by flow } \\
\text { regulation. } \\
\text { Riparian vegetation } \\
\text { covers the full length of } \\
\text { the segment but with } \\
\text { slightly reduced } \\
\text { coverage, being higher } \\
\text { than } 60 \% \text { of natural } \\
\text { coverage, and includes } \\
\text { several strata; or it } \\
\text { forms a dense but partly } \\
\text { fragmented corridor, } \\
\text { with open spaces less } \\
\text { than } 50 \text { m long, free of } \\
\text { land uses which may } \\
\text { compromise corridor or } \\
\text { filtering functions. // } \\
\text { Or continuity and } \\
\text { coverage of riparian } \\
\text { corridor slightly } \\
\text { promoted by flow } \\
\text { regulation, with an } \\
\text { increasing of tree } \\
\text { dominance. }\end{array}$} & \multicolumn{3}{|c|}{$\begin{array}{l}\text { Riparian corridor } \\
\text { moderately fragmented } \\
\text { or cleared by human } \\
\text { intervention, or } \\
\text { moderately induced by } \\
\text { flow regulation. } \\
\text { Riparian vegetation } \\
\text { covers the full length of } \\
\text { the segment but with } \\
\text { moderately reduced } \\
\text { coverage (between } \\
\text { 30\% and } 60 \% \text { of the } \\
\text { natural coverage), } \\
\text { including several strata, } \\
\text { or with a higher } \\
\text { coverage but only of } \\
\text { tree canopy layer. Or it } \\
\text { appears in patches, } \\
\text { leaving open spaces } \\
\text { more than } 50 \text { m long, } \\
\text { with agro-forest land } \\
\text { uses that moderately } \\
\text { compromise corridor } \\
\text { and filtering functions. } \\
\text { Or continuity and } \\
\text { coverage of riparian } \\
\text { corridor moderately } \\
\text { promoted by flow } \\
\text { regulation, showing a } \\
\text { continuous and dense } \\
\text { tree canopy layer } \\
\text { containing shrubs. }\end{array}$} & \multicolumn{3}{|c|}{$\begin{array}{l}\text { Riparian corridor } \\
\text { significantly } \\
\text { fragmented or cleared } \\
\text { by human intervention, } \\
\text { or significantly induced } \\
\text { by flow regulation. } \\
\text { Riparian vegetation } \\
\text { appears in small } \\
\text { patches covering less } \\
\text { than } 30 \% \text { of the length } \\
\text { of the segment, or } \\
\text { refers to isolated tree or } \\
\text { shrub individuals, with } \\
\text { scattered rushes or } \\
\text { bushes. } \\
\text { Or more than } 60 \% \text { of } \\
\text { the riparian area has no } \\
\text { vegetation and contains } \\
\text { urban or agricultural } \\
\text { occupations. // } \\
\text { Or riparian corridor } \\
\text { strongly promoted by } \\
\text { flow regulation, } \\
\text { containing only tree } \\
\text { species. }\end{array}$} & \multicolumn{3}{|c|}{$\begin{array}{l}\text { Riparian corridor } \\
\text { intensively altered by } \\
\text { human intervention. } \\
\text { Riparian vegetation is } \\
\text { reduced to isolated } \\
\text { trees or shrubs, leaving } \\
\text { large open areas with } \\
\text { buildings or land-uses } \\
\text { that severely } \\
\text { compromise corridor } \\
\text { and filtering functions. } \\
\text { Or there is no riparian } \\
\text { woody species and only } \\
\text { herbaceous } \\
\text { communities exist due } \\
\text { to human actions. } \\
\text { Use the score } 0 \text { in areas } \\
\text { where no woody } \\
\text { riparian species exist } \\
\text { (i.e. paved reaches) } \\
\text { where natural riparian } \\
\text { corridor functions are } \\
\text { completely prevented. }\end{array}$} \\
\hline 15 & 14 & 13 & 12 & 11 & 10 & 9 & 8 & 7 & 6 & 5 & 4 & 3 & 2 & 1 \\
\hline
\end{tabular}




\section{DESCRIPTION OF THE RQI METHODOLOGY}

\section{Rationale and spatial scale}

According to current scientific literature (e.g., Malanson, 1993; Hughes et al., 2003; Ward et al., 2002; Brierley \& Fryirs, 2005; Naiman et al., 2005; Hupp \& Rinaldi, 2007; Corenblit et al., 2009), the "natural conditions" of riparian systems should be defined in general terms by using the following characteristics:

- Extensive and continuous riparian corridors, occupying the banks and the total active floodplain area and including a more or less continuous vegetation corridor, of variable dimensions and coverage depending on valley type and natural constraints. The vegetation corridor connects with adjacent upland or terrestrial vegetation.

- Species composition typical of the biogeographical area and hydrogeomorphological conditions, with only native species and including natural regeneration.

- Dynamic banks with natural mobility resulting from erosion and deposition and the presence of geomorphological units characteristic of the flow regime and the calibre of transported materials.

- Lateral and vertical connectivity maintaining an exchange of organisms, matter and energy at different spatial and temporal scales.

To a great extent, these characteristics determine how riparian systems function and provide the environmental services.

The main ecological functions of the riparian zone are to provide a habitat and refuge for aquatic and terrestrial species, to facilitate biological connections in the landscape, to maintain plant diversity, to supply organic matter to aquatic food chains and to control stream water temperature. These functions are all related to the dimensions, the longitudinal continuity and the vegetation structure of riparian corridors (Malanson, 1993; Forman, 1999). Other hydro- logical and geomorphological riparian functions that are also essential for fluvial ecosystems, such as the retention of plant propagules, the reduction of bank erosion, the filtering of nutrients, sediment trapping, natural water purification, flood timing and energy dissipation, and infiltration and groundwater recharge are also very closely related to the structure of riparian vegetation, the dimensions of riparian corridors and lateral and vertical connectivity (FISRWG, 1998; Poole, 2002; Jansen et al., 2004; Naiman et al., 2005). Finally, apart from the functions already mentioned, riparian systems offer other environmental services of vital interest for human well-being, such as the provision of beauty, cultural inspiration and emotional values (Balmford et al., 2002). These characteristics also depend on the dimensions, continuity, sinuosity and naturalness of the riparian corridor.

The human impacts resulting from flow regulation, channelisation and floodplain occupancy gradually alter riparian conditions by reducing the width and continuity of riparian corridors, by promoting non-native species, by reducing natural regeneration, and by constraining lateral and vertical connectivity (Bendix \& Hupp, 2000; Nilsson \& Berggren. 2000; Tockner \& Stanford, 2002, Hughes \& Rood, 2003).

Based on the ecological principles of river behaviour, it is possible to assess the deviation of current riparian conditions from those corresponding to the "natural" or reference status and to establish a scoring system to evaluate the existing differences. In this sense, the RQI methodology attempts to take into account the main riparian components that perform the abovementioned functions and environmental services (González del Tánago \& García de Jalón, 2006) and to assess their gradual degradation or deviation from the theoretical reference conditions.

Consequently, riparian systems are assessed within the RQI using three physical attributes of their structure (land dimensions, longitudinal continuity and vegetation structure) and four other attributes related to their functioning (natural regeneration, bank condition, lateral connectivity and riparian substratum). The present conditions are compared with theoretical "natu- 
ral or reference" conditions, defined as the absence of human impacts and based on river typology. Tables 1 to 7 show the scoring systems proposed for these seven attributes. This approach aims not only to estimate the present status of riparian zones but also to identify the main features and causes of the existing constraints, thereby facilitating prioritisation and planning of restoration measures.

The RQI method is designed to be applied at the reach scale, where a relatively homogeneous riparian structure can be observed in terms of landscape (geology, vegetation and land use), valley and river type, flow conditions and floodplain characteristics. In general, these homogeneous conditions can be expected in the river segments between tributary confluences (Benda $e t$ al. 2004). However, other natural factors or manmade impacts, such as reservoirs, channelisation works, urbanisation, etc., can create riparian discontinuities and force consideration of separate reaches within the same river segment. For detailed surveys, a length of 500-1000 m for each study reach is recommended, with a predicted approximate time of at least thirty minutes for fielddata collection at each site.

Table 3. RQI Scores for assessing composition and structure of riparian vegetation status. Puntuaciones del RQI para evaluar el estado de la composición y estructura de la vegetación riparia.

\section{COMPOSITION AND STRUCTURE OF RIPARIAN VEGETATION}

Assess each margin separately. Identify natural composition and strata structure of riparian vegetation and natural succession stages for the study reach.

Look for differences between this potential vegetation and actual vegetation forms, number and coverage of exotic species and abundance of mats, reeds, nitrophilous or ruderal species.

\begin{tabular}{|c|c|c|c|c|c|c|c|c|c|c|c|c|c|c|}
\hline \multicolumn{3}{|c|}{ Very good } & \multicolumn{3}{|c|}{ Good } & \multicolumn{3}{|c|}{ Moderate } & \multicolumn{3}{|c|}{ Poor } & \multicolumn{3}{|c|}{ Bad } \\
\hline \multicolumn{3}{|c|}{$\begin{array}{l}\text { Riparian vegetation in } \\
\text { natural condition. } \\
\text { Riparian corridor } \\
\text { including a mix of } \\
\text { species corresponding } \\
\text { to the native vegetation } \\
\text { associations of the river } \\
\text { segment, with different } \\
\text { strata (canopy, } \\
\text { understory, ground) } \\
\text { often including shade } \\
\text { and climbing plants. No } \\
\text { exotic species. }\end{array}$} & \multicolumn{3}{|c|}{$\begin{array}{l}\text { Riparian vegetation } \\
\text { slightly altered by } \\
\text { human action. } \\
\text { Riparian corridor } \\
\text { containing most of the } \\
\text { species belonging to } \\
\text { native vegetation } \\
\text { associations of the river } \\
\text { segment. } 1 \text { or } 2 \text { exotic } \\
\text { species with less than } \\
10 \% \text { coverage. // } \\
\text { Scattered presence of } \\
\text { Rubus, mats or reeds } \\
\text { due to low-significant } \\
\text { riparian land-use. }\end{array}$} & \multicolumn{3}{|c|}{$\begin{array}{l}\text { Riparian vegetation } \\
\text { moderately altered by } \\
\text { human action. } \\
\text { Riparian corridor } \\
\text { containing only certain } \\
\text { species of potential } \\
\text { vegetation associations, } \\
\text { with scarcity of } \\
\text { understorey strata; or } \\
\text { including exotic species } \\
\text { with } 10-30 \% \text { coverage } \\
\text { // } \\
\text { Moderate presence of } \\
\text { Rubus, mats, reeds, } \\
\text { thorny, ruderal or } \\
\text { invasive herbaceous } \\
\text { species (coverage less } \\
\text { than } 30 \% \text { due to } \\
\text { moderate intensity of } \\
\text { riparian land-use. }\end{array}$} & \multicolumn{3}{|c|}{$\begin{array}{l}\text { Riparian vegetation } \\
\text { significantly altered by } \\
\text { human action. } \\
\text { Riparian corridor } \\
\text { containing only a small } \\
\text { representation of } \\
\text { potential vegetation } \\
\text { forms, or including } \\
\text { exotic species with } \\
30-60 \% \text { coverage. // } \\
\text { Abundance of Rubus } \\
\text { mats, reeds, thorny } \\
\text { ruderal or invasive } \\
\text { herbaceous species } \\
\text { (30-60 \% cover) due to } \\
\text { intensive riparian } \\
\text { land-use. }\end{array}$} & \multicolumn{3}{|c|}{$\begin{array}{l}\text { Riparian vegetation } \\
\text { badly altered by human } \\
\text { influence. } \\
\text { Riparian corridor with } \\
\text { more than } 60 \% \\
\text { coverage of exotic } \\
\text { species. Or dominance } \\
\text { of Arundo donax } \\
\text { formations, Rubus } \\
\text { mats, ruderal or } \\
\text { invasive species } \\
\text { (coverage larger than } \\
60 \% \text { ), or overgrowth } \\
\text { of dense herbaceous } \\
\text { communities along the } \\
\text { bank indicating } \\
\text { artificial maintenance } \\
\text { of water level, or } \\
\text { nitrogenous } \\
\text { enrichment. // } \\
\text { Riparian vegetation } \\
\text { only with grass due to } \\
\text { human influence. // } \\
\text { Consider score } 0 \text { when } \\
\text { soil bank is sealed or } \\
\text { paved and riparian } \\
\text { vegetation is } \\
\text { non-existent. }\end{array}$} \\
\hline 15 & 14 & 13 & 12 & 11 & 10 & 9 & 8 & 7 & 6 & 5 & 4 & 3 & 2 & 1 \\
\hline
\end{tabular}


The lateral dimensions of riparian areas, the longitudinal continuity and vegetation structure of these areas, and the vegetation associations to be identified may be analysed using aerial and satellite photographs in the office or laboratory by using landscape metrics and tools for digital image analysis. The results found for these characteristics may define a general riparian condition at a broad or reach scale. Information about species composition, natural regeneration, bank conditions, lateral connectivity and the riparian substratum must be collected through more detailed and field-based reconnaissance work. This information provides statements about more finely defined riparian conditions at a smaller scale.

\section{General information and assessment procedure}

Theoretically, the RQI methodology could be used in many different river types. Initially, it was based on typologies of Iberian rivers, which have catchment areas up to $100000 \mathrm{~km}^{2}$.

An analysis of recent aerial and satellite photographs of the river is recommended before the actual field work begins. This analysis is useful for gaining an improved visualisation of the homogeneity of the riparian conditions and the continuity of the river corridor. It also permits a proper selection of representative field study sites. These sites will then better reflect the status of the entire study area. Prior knowledge of the following characteristics is also necessary:

Table 4. RQI Scores for assessing age diversity and natural regeneration status of woody riparian vegetation. Puntuaciones del RQI para evaluar la diversidad de edades y el estado de regeneración natural de la vegetación riparia.

\section{AGE DIVERSITY AND NATURAL REGENERATION OF WOODY SPECIES}

Assess both margins jointly. Look for age diversity of main woody species. Try to locate where regeneration takes place and search for the main causes limiting regeneration when they exist.

\begin{tabular}{|c|c|c|c|c|c|c|c|c|c|c|c|c|c|c|}
\hline \multicolumn{3}{|c|}{ Very good } & \multicolumn{3}{|c|}{ Good } & \multicolumn{3}{|c|}{ Moderate } & \multicolumn{3}{|c|}{ Poor } & \multicolumn{3}{|c|}{ Bad } \\
\hline \multicolumn{3}{|c|}{$\begin{array}{l}\text { Age diversity and } \\
\text { regeneration of woody } \\
\text { species in natural } \\
\text { conditions. } \\
\text { All age classes } \\
\text { (seedlings, young, adult } \\
\text { and mature individuals) } \\
\text { of all woody species } \\
\text { are observed in the } \\
\text { riparian zone. // } \\
\text { Or without human } \\
\text { activities affecting } \\
\text { natural riparian species } \\
\text { regeneration. }\end{array}$} & \multicolumn{3}{|c|}{$\begin{array}{l}\text { Age diversity and } \\
\text { regeneration of woody } \\
\text { species slightly altered } \\
\text { by human action. } \\
\text { All age classes } \\
\text { (seedlings, young, adult } \\
\text { and mature individuals) } \\
\text { of main woody species } \\
\text { are observed at least in } \\
\text { some locations within } \\
\text { the entire riparian zone, } \\
\text { but missing the } \\
\text { youngest age classes of } \\
\text { the most sensitive } \\
\text { species. } \\
\text { Human interventions } \\
\text { with little effect on } \\
\text { natural regeneration. }\end{array}$} & \multicolumn{3}{|c|}{$\begin{array}{l}\text { Age diversity and } \\
\text { regeneration of woody } \\
\text { species moderately } \\
\text { altered by human } \\
\text { action. } \\
\text { Regeneration is } \\
\text { confined to the pioneer } \\
\text { species and only takes } \\
\text { place in the proximal } \\
\text { riparian zone. In the } \\
\text { distal zone only adults } \\
\text { and mature individuals } \\
\text { are observed, with } \\
\text { scarce representation of } \\
\text { the youngest age } \\
\text { classes. } \\
\text { Human interventions } \\
\text { with moderate effect on } \\
\text { natural regeneration } \\
\text { due to low-intense } \\
\text { regulation of flows, soil } \\
\text { ploughing, periodical } \\
\text { fire, cattle grazing, etc. }\end{array}$} & \multicolumn{3}{|c|}{$\begin{array}{l}\text { Age diversity and } \\
\text { regeneration of woody } \\
\text { species significantly } \\
\text { altered by human } \\
\text { action. } \\
\text { Regeneration restricted } \\
\text { to } 1-2 \text { species, and to } \\
\text { the banks. In the rest of } \\
\text { the riparian area only } \\
\text { adults or mature } \\
\text { individuals are } \\
\text { observed. } \\
\text { Human interventions } \\
\text { with significant effect } \\
\text { on natural regeneration } \\
\text { due to herbicides, } \\
\text { channelization, water } \\
\text { contamination, intense } \\
\text { flow regulation, etc. }\end{array}$} & \multicolumn{3}{|c|}{$\begin{array}{l}\text { Age diversity and } \\
\text { regeneration of woody } \\
\text { species badly altered by } \\
\text { human action. } \\
\text { No or very little } \\
\text { regeneration is } \\
\text { observed, with very } \\
\text { scarce youngest age } \\
\text { classes and only in the } \\
\text { sand or gravel } \\
\text { bank-attached forms } \\
\text { emerging in the active } \\
\text { channel. In the rest of } \\
\text { the riparian area only } \\
\text { mature specimens exist, } \\
\text { together with frequent } \\
\text { dead individuals. } \\
\text { Severe restrictions due } \\
\text { to human action, } \\
\text { preventing vegetation } \\
\text { establishment. Use } \\
\text { score } 0 \text { when riparian } \\
\text { zone is completely } \\
\text { sealed or paved, with } \\
\text { no regeneration } \\
\text { potential. }\end{array}$} \\
\hline 15 & 14 & 13 & 12 & 11 & 10 & 9 & 8 & 7 & 6 & 5 & 4 & 3 & 2 & 1 \\
\hline
\end{tabular}


- Flow regime data, presence of dams along the surveyed river and dam management information

- Human activities that may not be visible during field visits or that were conducted in the past (gravel mining, landfill, agricultural practices, controlled fire, grazing, periodic clearcuts, selective vegetation removal, etc.)

- Potential up-slope or terrestrial vegetation along adjacent margins

- Natural riparian vegetation associations for the study area. Morphological characteristics and habitat requirements of native and non- native species used for their identification and for determining their ecological indicator value (i.e., nemoral, ruderal, nitrophilous, etc.)

In the field, before data collection, the following characteristics must be analysed:

- Valley and channel type, in order to estimate the potential extension of riparian and floodplain areas (González del Tánago et al., 2006). Basically, the following typologies should be taken into account (Brierley \& Fryirs, 2005): (1) confined valleys, symmetrical, with the slopes connected directly with the channel. In this case, riparian zones

Table 5. RQI Scores for assessing active channel bank conditions. Puntuaciones del RQI para evaluar el estado de las orillas del cauce activo.

\section{BANK CONDITIONS}

Assess both margins jointly, referred to river banks at bank-full discharge. Look for indicators of naturalness (mobility, bankattached land forms, presence of woody debris and vegetation detritus, heterogeneity of water shore, etc.). Search for human influence determining bank instability, homogeneity of water shore, vegetation overgrowth in banks, incision or fine sediment deposition, revetments or direct alterations of bank-form, bank-height and bank-slope.

\begin{tabular}{|c|c|c|c|c|c|c|c|c|c|c|c|c|c|c|}
\hline \multicolumn{3}{|c|}{ Very good } & \multicolumn{3}{|c|}{ Good } & \multicolumn{3}{|c|}{ Moderate } & \multicolumn{3}{|c|}{ Poor } & \multicolumn{3}{|c|}{ Bad } \\
\hline \multicolumn{3}{|c|}{$\begin{array}{l}\text { Banks in natural } \\
\text { condition. } \\
\text { Banks normally with } \\
\text { heterogeneous water } \\
\text { shoreline associated to } \\
\text { natural bank-attached } \\
\text { forms. Abundance of } \\
\text { dead wood and } \\
\text { vegetation detritus at } \\
\text { lateral sides of channel. } \\
\text { Fully developed } \\
\text { riparian plant } \\
\text { community firmly } \\
\text { binding bank sediments } \\
\text { along the total reach. } \\
\text { Local erosion and } \\
\text { sedimentation } \\
\text { processes associated } \\
\text { with channel bends } \\
\text { could be observed, for } \\
\text { example cliffs in the } \\
\text { outer banks of meander, } \\
\text { not related to human } \\
\text { actions. // } \\
\text { Channel morphology } \\
\text { without human } \\
\text { alterations. }\end{array}$} & \multicolumn{3}{|c|}{$\begin{array}{l}\text { Banks slightly modified } \\
\text { by human action. } \\
\text { Banks forms and } \\
\text { processes are altered in } \\
\text { less than } 10 \% \text { of total } \\
\text { length. Presence of } \\
\text { dead wood and } \\
\text { vegetation detritus at } \\
\text { lateral sides of channel. } \\
\text { Natural fully developed } \\
\text { riparian plant } \\
\text { community binding the } \\
\text { bank sediments in more } \\
\text { than } 60 \% \text { of total } \\
\text { length and local erosion } \\
\text { and sedimentation } \\
\text { processes associated } \\
\text { with low impact of } \\
\text { human interventions } \\
\text { affect less than } 10 \% \text { of } \\
\text { total length. // } \\
\text { Channel cross-section } \\
\text { slightly altered by } \\
\text { human action, but } \\
\text { without stabilization } \\
\text { measures. }\end{array}$} & \multicolumn{3}{|c|}{$\begin{array}{l}\text { Banks moderately } \\
\text { modified by human } \\
\text { action. } \\
\text { Banks shape and } \\
\text { processes moderately } \\
\text { altered, devoid of } \\
\text { vegetation and showing } \\
\text { undercutting or mass } \\
\text { failure due to human } \\
\text { influence in } 10-30 \% \text { of } \\
\text { total length; or partially } \\
\text { fixed with rip-rap or } \\
\text { bioengineering } \\
\text { techniques in less than } \\
30 \% \text { of total length // } \\
\text { Emerging incision or } \\
\text { bank accretion due to } \\
\text { fine sediments } \\
\text { deposition In less than } \\
30 \% \text { of reach length. // } \\
\text { Channel cross-section } \\
\text { moderately altered by } \\
\text { human action, with } \\
\text { increased banktop } \\
\text { height at both margins } \\
\text { forming side-slopes } \\
\text { with average slope } \\
\text { smaller than } 1 \mathrm{~V}: 4 \text { H. }\end{array}$} & \multicolumn{3}{|c|}{$\begin{array}{l}\text { Banks significantly } \\
\text { modified by human } \\
\text { action. } \\
\text { Banks shape and } \\
\text { processes significantly } \\
\text { altered, devoid of } \\
\text { vegetation and showing } \\
\text { undercutting or mass } \\
\text { failure due to human } \\
\text { influence in } 30-60 \% \text { of } \\
\text { total length; or fixed } \\
\text { with rip-rap or } \\
\text { bioengineering } \\
\text { techniques along } \\
30-60 \% \text { of total length. } \\
\text { // } \\
\text { Moderate incision } \\
\text { processes or significant } \\
\text { accumulation of fine } \\
\text { sediments in } 30-60 \% \\
\text { of total length. // } \\
\text { Channel cross-section } \\
\text { significantly altered by } \\
\text { human intervention, } \\
\text { over-deepened or with } \\
\text { increased banktop } \\
\text { height, forming mean } \\
\text { side-slopes between } \\
1 \mathrm{~V}: 4 \text { H and } 1 \mathrm{~V}: 2 \mathrm{H} \text {. }\end{array}$} & \multicolumn{3}{|c|}{$\begin{array}{l}\text { Banks badly altered by } \\
\text { human action. } \\
\text { Banks fixed with } \\
\text { bio-engineering or } \\
\text { rip-rap revetments } \\
\text { covering more than } \\
60 \% \text { of the total } \\
\text { length. / / } \\
\text { Significant incision or } \\
\text { bank accretion due to } \\
\text { massive fine sediment } \\
\text { deposition along more } \\
\text { than } 60 \% \text { of the } \\
\text { segment length. // } \\
\text { Channel cross-section } \\
\text { significantly altered by } \\
\text { human intervention, } \\
\text { over-deepened or with } \\
\text { lateral embankments at } \\
\text { both margins, forming } \\
\text { uniform side-slopes } \\
\text { steeper than } 1 \mathrm{~V}: 2 \mathrm{H} \text {. } \\
\text { Consider score } 0 \text { when } \\
\text { the banks are all paved } \\
\text { and covered by } \\
\text { concrete and any } \\
\text { growth of vegetation is } \\
\text { prevented. }\end{array}$} \\
\hline 15 & 14 & & 12 & 11 & 10 & & 8 & 7 & & & & & & 1 \\
\hline
\end{tabular}


are expected to be narrow, containing mixed forest with upland and riparian species, without a floodplain; (2) partly-confined valleys, asymmetrical, characteristics on one margin similar to those of confined valleys, characteristics on the other margin similar to wider riparian areas connected with discontinuous floodplain, and with riparian forest that may extend through the unconfined area; and (3) unconfined valleys, both margins having the channel and hill-slopes disconnected and buffered by a continuous floodplain, and with a riparian forest that may be wider.

- Transversal zonation according to channel morphology, with identification of the lower areas of banks and bank-attached geomorphic units. Under natural conditions, woody vegetation restricting natural channel mobility should not be dominant; in the banktop and riparian proximal areas that are more exposed to shear stress during high flows, species that are better adapted to drag forces (more flexible stems and easy regeneration and short-lived species) should be found. The natural dynamic processes of erosion and sedimentation should be observed, at least on one margin. In the riparian distal areas in the active floodplain, less exposed to the force of the current, mature forests should remain.

Table 6. RQI Scores for assessing lateral connectivity status of riparian and floodplain areas. Puntuaciones del RQI para evaluar el estado de la conectividad lateral de las riberas y llanuras de inundación

\section{FLOODS AND LATERAL CONNECTIVITY}

Assess both margins jointly. Look for intensity of flow regulation altering frequency and magnitude of floods and periodicity and area of flooding; and identify morphological changes or channelization works for preventing overflowing. In absence of flow data, look for inundation footprints on riparian and floodplain areas, such as woody debris and wastes hanging on vegetation after floods, open gravel and sand areas associated to secondary flood channels, vegetation detritus location, etc. Or assess lateral connectivity based on proximity of physical visible restrictions of flow accessibility to riparian zone.

\begin{tabular}{|c|c|c|c|c|c|c|c|c|c|c|c|c|c|c|}
\hline \multicolumn{3}{|c|}{ Very good } & \multicolumn{3}{|c|}{ Good } & \multicolumn{3}{|c|}{ Moderate } & \multicolumn{3}{|c|}{ Poor } & \multicolumn{3}{|c|}{ Bad } \\
\hline \multicolumn{3}{|c|}{$\begin{array}{l}\text { Natural flow regime } \\
\text { and flood free access to } \\
\text { riparian zones. } \\
\text { Channel and floodplain } \\
\text { topography in natural } \\
\text { conditions, without any } \\
\text { restrictions to over } \\
\text { bank flooding. } \\
\text { Abundance of dead } \\
\text { wood and woody } \\
\text { branches along the } \\
\text { floodplain transported } \\
\text { by large floods. }\end{array}$} & \multicolumn{3}{|c|}{$\begin{array}{l}\text { Floods and lateral } \\
\text { connectivity slightly } \\
\text { controlled by human } \\
\text { action. } \\
\text { Flow regulation with } \\
\text { small reduction of } \\
\text { bank-full discharge or } \\
\text { natural ordinary floods } \\
\text { frequency (return } \\
\text { period between } 2-10 \\
\text { years**); overflowing } \\
\text { occurs at least two } \\
\text { times every } 10 \text { years } \\
\text { and inundates more } \\
\text { than } 50 \% \text { of riparian } \\
\text { width. Presence of dead } \\
\text { wood and woody } \\
\text { branches along the } \\
\text { banks transported by } \\
\text { floods. // } \\
\text { Or slight restrictions to } \\
\text { flooding by small } \\
\text { embankments located } \\
\text { at a distance from the } \\
\text { bank larger than } 3 \\
\text { active channel widths. }\end{array}$} & \multicolumn{3}{|c|}{$\begin{array}{l}\text { Floods and lateral } \\
\text { connectivity moderately } \\
\text { controlled by human } \\
\text { action. } \\
\text { Flow regulation with } \\
\text { moderate reduction of } \\
\text { magnitude and } \\
\text { frequency of natural } \\
\text { ordinary floods. } \\
\text { Overflowing occurs at } \\
\text { least once every } 10 \\
\text { years and inundates } \\
\text { more than } 30 \% \text { of } \\
\text { riparian width. } \\
/ / \text { Or moderate } \\
\text { restrictions to flooding, } \\
\text { due to embankments } \\
\text { located at a distance } \\
\text { from the bank between } \\
1 \text { and } 3 \text { active channel } \\
\text { widths, or due to a } \\
\text { moderate deepening of } \\
\text { channel. }\end{array}$} & \multicolumn{3}{|c|}{$\begin{array}{l}\text { Floods and lateral } \\
\text { connectivity } \\
\text { significantly controlled } \\
\text { by human action. } \\
\text { Flow regulation with } \\
\text { significant reduction of } \\
\text { magnitude and } \\
\text { frequency of natural } \\
\text { floods; overflowing } \\
\text { occurs only with large } \\
\text { and low- frequent } \\
\text { floods, around once } \\
\text { every } 25 \text { years. } \\
\text { // Or significant } \\
\text { restrictions to flooding, } \\
\text { due to river training and } \\
\text { hydraulic engineering } \\
\text { with embankments } \\
\text { located at a distance } \\
\text { from the bank less than } \\
\text { one active channel } \\
\text { width, or due to } \\
\text { significant incision of } \\
\text { channel. }\end{array}$} & \multicolumn{3}{|c|}{$\begin{array}{l}\text { Floods and lateral } \\
\text { connectivity badly } \\
\text { reduced by human } \\
\text { action. } \\
\text { Flow regulation with } \\
\text { severe reduction of } \\
\text { magnitude and } \\
\text { frequency of natural } \\
\text { floods; overflowing } \\
\text { occurs rarely, only with } \\
\text { very large floods, less } \\
\text { than once every } 25 \\
\text { years // } \\
\text { Hard channelization } \\
\text { works that severely } \\
\text { reduce the flood-prone } \\
\text { area. } \\
\text { Consider score } 0 \text { in } \\
\text { cases of very intense } \\
\text { flow regulation or hard- } \\
\text { engineered reaches } \\
\text { where only very } \\
\text { extraordinary flows can } \\
\text { inundate river margins. }\end{array}$} \\
\hline 15 & 14 & 13 & 12 & 11 & 10 & 9 & 8 & 7 & 6 & 5 & 4 & 3 & 2 & 1 \\
\hline
\end{tabular}

** Ordinary floods include the annual maximum flows around bank-full discharge, in which the return period usually oscillates between 1,5-2 years in the permanent and more regular flow regimes, and 5-8 years in the temporal and with more variability flow regimes of semi-arid regions (Dunne \& Leopold, 1978; Estrela, 1994). 
Table 7. RQI Scores for assessing riparian substratum and vertical connectivity status. Puntuaciones del RQI para evaluar la calidad del substrato de las riberas y su conectividad vertical

\section{SUBSTRATUM AND VERTICAL CONNECTIVITY}

Assess both margins jointly. Look for alterations of soil surface reducing natural infiltration capacity; and for alterations of substratum along soil profile that reduce original alluvial permeability, subsurface flows and groundwater connectivity. Alterations can be due to fillings that modify original soil material and seed-bank and reduce composition and diversity of native herbaceous communities: or to gravel mining that induces particle size changes or replaces original materials; or due to the presence of underground infrastructures that prevent subsurface flows.

\begin{tabular}{|c|c|c|c|c|c|c|c|c|c|c|c|c|c|c|}
\hline \multicolumn{3}{|c|}{ Very good } & \multicolumn{3}{|c|}{ Good } & \multicolumn{3}{|c|}{ Moderate } & \multicolumn{3}{|c|}{ Poor } & \multicolumn{3}{|c|}{ Bad } \\
\hline \multicolumn{3}{|c|}{$\begin{array}{l}\text { Riparian soil and } \\
\text { subsurface flows in } \\
\text { natural condition. } \\
\text { Soil surface covered by } \\
\text { vegetation detritus and } \\
\text { herbaceous plants, with } \\
\text { original seed-bank and } \\
\text { diversity of grass } \\
\text { communities, and non } \\
\text { altered infiltration } \\
\text { capacity. } \\
\text { Riparian substratum in } \\
\text { natural condition, } \\
\text { maintaining its original } \\
\text { permeability. } \\
\text { Preservation of } \\
\text { subsurface flows and } \\
\text { groundwater natural } \\
\text { connectivity. }\end{array}$} & \multicolumn{3}{|c|}{$\begin{array}{l}\text { Riparian soil slightly } \\
\text { modified by human } \\
\text { actions. } \\
\text { Soil surface covered by } \\
\text { vegetation detritus and } \\
\text { grass in more than two } \\
\text { thirds of the area. Bare } \\
\text { zones, small trails or } \\
\text { non-paved compacted } \\
\text { areas due to cattle } \\
\text { grazing, vehicles or } \\
\text { recreation activities } \\
\text { representing less than } \\
\text { one third of the area, } \\
\text { with no significant } \\
\text { reduction of infiltration } \\
\text { capacity along the } \\
\text { study reach. } \\
\text { Substratum in natural } \\
\text { condition, preserving } \\
\text { natural seed-bank, } \\
\text { herbaceous } \\
\text { communities and } \\
\text { original permeability. } \\
\text { Gravel mining and } \\
\text { alterations to soil } \\
\text { topography absent or of } \\
\text { low significance, and } \\
\text { connectivity of } \\
\text { subsurface and } \\
\text { groundwater flows is } \\
\text { maintained. } \\
\text { No fillings or } \\
\text { excavations. }\end{array}$} & \multicolumn{3}{|c|}{$\begin{array}{l}\text { Riparian soil } \\
\text { moderately modified by } \\
\text { human actions. } \\
\text { Soil surface covered by } \\
\text { vegetation detritus and } \\
\text { grass in less than two } \\
\text { thirds of the area. Soil } \\
\text { surface ploughed, } \\
\text { sealed or paved in less } \\
\text { than } 30 \% \text { moderately } \\
\text { reducing infiltration } \\
\text { capacity. } \\
\text { Or soil profile has been } \\
\text { altered in less than } \\
30 \% \text { of riparian area, } \\
\text { because of gravel } \\
\text { mining (topography } \\
\text { and substrate particle } \\
\text { size with moderate } \\
\text { alterations), or } \\
\text { sediment deposits } \\
\text { (original seed-bank } \\
\text { altered showing } \\
\text { abundance of pioneer } \\
\text { opportunistic } \\
\text { herbaceous plants or } \\
\text { dominance of bare } \\
\text { soil). // } \\
\text { Addition of inert } \\
\text { materials, solid wastes } \\
\text { or building debris in } \\
\text { less than } 30 \% \text { of the } \\
\text { area moderately alters } \\
\text { natural permeability } \\
\text { and connectivity with } \\
\text { subsurface and } \\
\text { groundwater flows. // } \\
\text { Presence of } \\
\text { underground } \\
\text { infrastructures as roads } \\
\text { or pipes (water, } \\
\text { electricity, oil) or } \\
\text { addition of solid wastes } \\
\text { or building debris } \\
\text { affects less than } 30 \% \\
\text { of the area. }\end{array}$} & \multicolumn{3}{|c|}{$\begin{array}{l}\text { Riparian soil } \\
\text { significantly modified } \\
\text { by human actions. } \\
\text { Soil surface sealed, } \\
\text { compacted or paved in } \\
30-60 \% \text { of the area, } \\
\text { significantly reduce } \\
\text { infiltration capacity. } \\
\text { Or soil profile has been } \\
\text { altered in } 30-60 \% \text { of } \\
\text { riparian area, because } \\
\text { of gravel mining } \\
\text { (topography and } \\
\text { substrate particle size } \\
\text { with moderate } \\
\text { alterations), or } \\
\text { sediment deposits } \\
\text { (original seed-bank } \\
\text { altered showing } \\
\text { abundance of pioneer } \\
\text { opportunistic } \\
\text { herbaceous plants or } \\
\text { dominance of bare } \\
\text { soil). // Riparian } \\
\text { substratum substituted } \\
\text { by inert materials, solid } \\
\text { wastes or building } \\
\text { debris in } 30-60 \% \text { of } \\
\text { the riparian area. // } \\
\text { Presence of } \\
\text { underground } \\
\text { infrastructures as roads } \\
\text { or pipes (water, } \\
\text { electricity, oil) or } \\
\text { addition of solid wastes } \\
\text { or building debris } \\
\text { affects } 30-60 \% \text { of the } \\
\text { area, significantly } \\
\text { altering subsurface } \\
\text { flows and groundwater } \\
\text { connectivity. }\end{array}$} & \multicolumn{3}{|c|}{$\begin{array}{l}\text { Riparian soil badly } \\
\text { modified by human } \\
\text { actions. } \\
\text { Riparian soils sealed or } \\
\text { paved in more than } \\
60 \% \text { of the area, } \\
\text { severely compromise } \\
\text { infiltration of water. } \\
\text { Or soil profile has been } \\
\text { deeply altered by gravel } \\
\text { extraction, or by } \\
\text { topography alterations } \\
\text { degrading original soil } \\
\text { and seed-bank in more } \\
\text { than } 60 \% \text { of the area. // } \\
\text { Riparian substratum } \\
\text { substituted by inert } \\
\text { materials, solid wastes } \\
\text { or building debris in } \\
\text { more than } 60 \% \text { of the } \\
\text { riparian area. // } \\
\text { Underground } \\
\text { infrastructures as roads } \\
\text { or pipes (water, } \\
\text { electricity, oil) or } \\
\text { addition of solid wastes } \\
\text { or building debris } \\
\text { affecting more than } \\
60 \% \text { of the area, with } \\
\text { strong alteration of } \\
\text { subsurface flows and } \\
\text { groundwater } \\
\text { connectivity. } \\
\text { Use score } 0 \text { when } \\
\text { riparian zones are } \\
\text { completely paved or } \\
\text { excavated containing } \\
\text { concrete infrastructures } \\
\text { preventing any } \\
\text { hydrological } \\
\text { connectivity with } \\
\text { channel. }\end{array}$} \\
\hline 15 & 14 & 13 & 12 & 11 & 10 & 9 & 8 & 7 & 6 & 5 & & 3 & 2 & 1 \\
\hline
\end{tabular}


Table 8. Interpretation of total RQI score values and proposal of river management options. Interpretación de los valores totales de RQI y propuestas de gestión.

\begin{tabular}{|c|c|c|}
\hline RQI value & Riparian status & Management options \\
\hline $150-130$ & Very good & $\begin{array}{l}\text { Riparian attributes in natural conditions, without threats in their functioning. } \\
\text { Great interest in Conservation and Protection, to maintain current status and prevent future } \\
\text { alterations of riparian systems }\end{array}$ \\
\hline $129-100$ & Good & $\begin{array}{l}\text { Most of the attributes are in good or very good conditions and one or two can be altered. } \\
\text { Riparian systems need Protection measures to prevent potential new impacts and Restoration } \\
\text { measures to achieve full integrity of riparian functions. Eliminate pressures and impacts as much } \\
\text { as possible. }\end{array}$ \\
\hline $99-70$ & Moderate & $\begin{array}{l}\text { Several attributes are moderately altered. } \\
\text { Riparian systems require Restoration measures to assure proper hydrological and ecological } \\
\text { functioning. Eliminate or Reduce pressures and impacts as much as possible. }\end{array}$ \\
\hline $69-40$ & Poor & $\begin{array}{l}\text { Most attributes are moderately altered. } \\
\text { Riparian systems need Rehabilitation or Restoration measures, to improve and recover hydro- } \\
\text { logical and ecological riparian functions. Reduce pressures and impacts as much as possible and } \\
\text { design compensation measures to ameliorate environmental conditions. }\end{array}$ \\
\hline $39-10$ & Bad & $\begin{array}{l}\text { Several attributes are poorly altered. } \\
\text { Riparian systems need Rehabilitation or Restoration measures to reintroduce or gradually } \\
\text { improve hydrological and ecological riparian functions. Reduce pressures and impacts as } \\
\text { possible and ameliorate the social perception of river degradation. }\end{array}$ \\
\hline$<10$ & Very bad & $\begin{array}{l}\text { Most of the attributes are badly altered. } \\
\text { Riparian systems need new Rehabilitation or Remediation works, to recreate and reintroduce } \\
\text { riparian functions. Improve environmental conditions for good potential status and ameliorate } \\
\text { the social perception of river degradation. }\end{array}$ \\
\hline
\end{tabular}

In each study site, field data should be systematically recorded using the data sheets of Annex I. For riparian system assessment, Tables 1 to 3 should be applied to each river bank separately. Six scores will result. Tables 4 to 7 should be applied to integrate the riparian status of both margins. Here, four additional scores will be obtained. The final result of the RQI at each study site is then obtained by summing these 10 score values. The summed values will range from 130-150 (best status) to less than 10 (worst or very bad conditions). Depending on the study objectives and constraints, one or several study sites can be used to represent the overall status of each river reach surveyed.

Appropriate maps can provide edited versions of the results. Maps of each attribute scored may be prepared to reflect the more frequent or extensive limiting factors for riparian areas within the basin studied. Maps of the total RQI values are useful to represent the global quality of each riparian area and to show the locations of the best-preserved river reaches.
Management options related to global-quality classes are suggested in Table 8. More detailed restoration or rehabilitation strategies and measures may be derived from the information shown on individual maps of the riparian attributes assessed. Overlaying the RQI value maps with other Geographical Information Systems (GIS) layers, such as land use, protected areas (such as those protected under the European Habitat Directive), flow regulation structures, urbanisation density, water quality, etc., may help to relate the present riparian status to potential sources of degradation. This approach may also help to establish criteria and to develop a rationale for planning rehabilitation or restoration programmes and priorities.

\section{RQI METHODOLOGY APPLICATIONS}

The initial version of the RQI methodology was applied in several regions and basins of the Iberian Peninsula to demonstrate the usefulness and potential applications of the method. The 


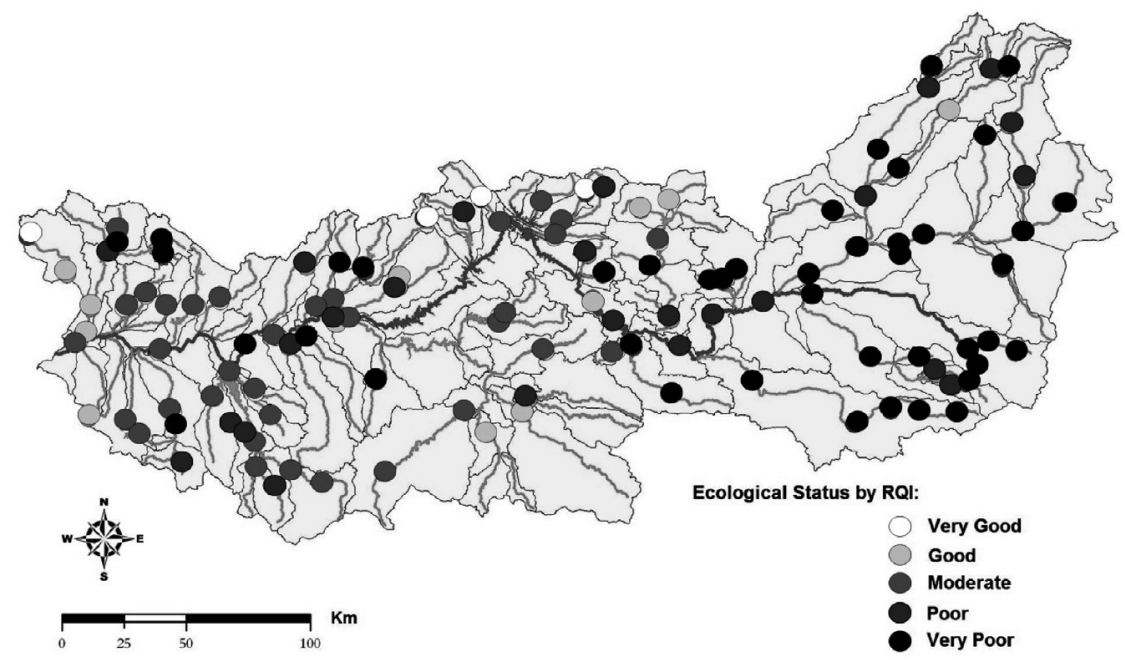

Figure 1. Map of Riparian Quality of the Guadiana Basin using the RQI methodology in 120 study-sites (González del Tánago et al., 2004). Mapa de calidad de las riberas de la Cuenca del Guadiana utilizando la metodología RQI en 120 lugares de estudio (González del Tánago et al., 2004).

index was initially used in the Guadiana basin. This analysis involved a study of 130 surveyed stations and allowed the diagnosis of the status of the fluvial riparian systems at basin scale
(González del Tánago et al., 2004). Figures 1 and 2 shows the results of this work, including the spatial relationships between riparian quality and land use. The best-preserved sections corre-

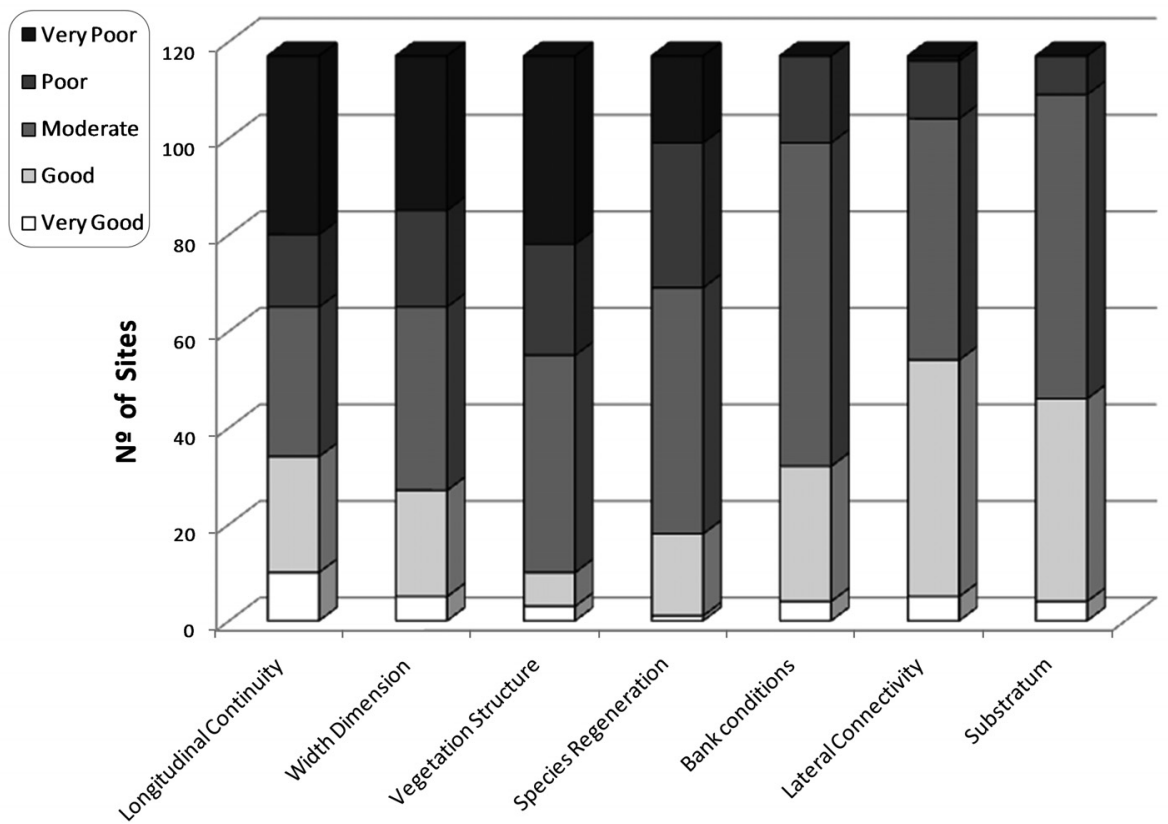

Figure 2. Status of each riparian attribute assessed by the RQI in the 120 study-sites of the Guadiana Basin (González del Tánago et al., 2004). Estado de cada uno de los atributos de las riberas estudiados con el RQI en 120 estaciones de la Cuenca del Guadiana (González del Tánago et al., 2004). 
spond to the upper reaches of forest streams located in Montes de Toledo. The most-degraded reaches are located in La Mancha (Ciudad Real), where river channel dredging and alignment in flat valleys were carried out for agricultural purposes during the 1970 s, causing further incision processes, and in several reaches of the Guadiana tributaries, where fragmentation or reduction in lateral connectivity owing to agriculture and flow regulation occurred with greater effect. Based on these results, the creation of buffer strips along lowland rivers to increase the continuity and extension of the riparian corridor was considered one of the most urgent measures for the rehabilitation of riparian zones in the Guadiana Basin. The basin should be protected by controlling grazing and agricultural practices to promote the regeneration of native woody species.

The RQI index was also applied for different purposes in other regions. Francés et al. (2009) have used the RQI to compare riparian conditions under natural and regulated flow regimes. In the region of La Rioja, Alonso et al. (2007) have applied this index to assess the riparian conditions as an important component of the physical habitat of fish communities. Iturriaga (2007) has made a statistical comparison of RQI with two other Spanish indices, QBR (Munné et al., 1998) and IFH (Pardo et al. 2002). This work was carried out in the rivers of Navarra. This analysis found that RQI was correlated to a certain extent with QBR and IFH. The resulting $\mathrm{R}^{2}$ values were 0.79 and 0.67 , respectively. Nevertheless, RQI was considered more useful, as it explicitly takes into account longitudinal continuity, natural regeneration and lateral and vertical connectivity. The other indices do not include these factors, which are considered crucial for assessing the maintenance and functionality of riparian corridors.

\section{DISCUSSION}

The proposed RQI methodology represents a useful tool for the characterisation and quick assessment of the environmental conditions present in riparian systems. This method helps in the diagnosis and the design of restoration strategies by furnishing a checklist of the main riparian components affected by human activities.

The RQI index takes into account the major components of the structure and functioning of riparian zones, and it offers more complete criteria for riparian assessment than those included in previously available methods. It accounts for the main riparian components performing the ecological and hydrological functions of the riparian zone, and it incorporates river dynamics and natural riparian vegetation regeneration as important attributes that reflect not only the present status but also possible future conditions, given the current circumstances of flow regime, land use or channel management.

The assessment of several riparian attributes has been improved in the new version of RQI. In addition, different levels of fragmentation vs. longitudinal continuity are now considered. The length and the land-use intensity of open patches are referenced as the main indicators of riparian structural connectivity (Goodwin, 2003: Calabrese \& Fagan, 2004). Local erosion and sedimentation processes under specific conditions are considered in the new version of RQI as indicators of river mobility and "naturalness." These characteristics indicate good to very good status in several cases, according to Corenblit et al. (2007), whereas they could have been interpreted as river instability and scored as fair or bad conditions in the previous version of the Index.

Other improvements in this new version of RQI are the simplification of the assessment of vegetation structure. Different vegetation bands are no longer distinguished because their identification may be rather subjective. The presence of large woody debris on banks and floodplains has been added to indicate lateral connectivity and good to very good riparian status.

Finally, additional suggestions have been included. The new version recommends that some information be collected prior to performing the field work, and that the survey sites be selected according to the study objectives using aerial and satellite photographs. The improvements of the new version of RQI methodology can assist in its application, enlarging the awareness of the users who perform riparian system diagnosis and evaluation. 
The RQI index was designed to be suitable for a wide range of Iberian river types, including permanent and temporary streams, in both the Mediterranean and the Atlantic climates and for basin areas up to $100000 \mathrm{~km}^{2}$. It has been applied to many different rivers under very distinct hydrological and morphological conditions. However, it is not used for ephemeral streams, whose riparian vegetation may respond to different factors. It is important to note that the "very good" or reference conditions of the seven attributes measured are always referred to the river type and that the criteria to assess the gradual degradation of riparian systems correspond to physical processes occurring everywhere. These characteristics suggest that the RQI methodology could be adapted easily to other conditions not yet tested, including very large rivers (basin area $>100000 \mathrm{~km}^{2}$ ), tidal-influenced reaches, borealalpine rivers, and more. The specific conditions present in each case should be taken into account by considering different natural features and degradation responses.

The systematic application of the RQI methodology allows riparian-quality maps to be constructed at different spatial scales in response to an overall assessment of RQI score or an individualised assessment of the riparian attributes throughout the basin. It can be applied at different times to compare quantitative data on riparian characteristics in different years, thereby facilitating the evaluation of riparian recovery or degradation after human interventions and offering many valuable criteria for ecological post-project appraisals.

\section{ACKNOWLEDGEMENTS}

We wish to acknowledge the comments and suggestions made by Arturo Elosegi, Joserra Díaz y Moraia Grau regarding the addition of new elements of riparian assessment. We are also very grateful to Francisco Martínez-Capel, Carlos Alonso, Dolores Bejarano, Judit Maroto and the rest of the Hydrobiology Research Group at the Polytechnical University of Madrid for their help in sharing their experience with RQI ap- plications and for their comments. Two anonymous reviewers have helped to improve the manuscript significantly.

\section{REFERENCES}

ALONSO, C., P.VIZCAIINO, J.CORTÁZAR,D. BAEZA, M. MARCHAMALO, M. VALLE \& D. GARCÍA DE JALÓN. 2007. Plan de ordenación piscícola de La Rioja: Planes hidrobiológicos. Informe Técnico, Gobierno de La Rioja-Ecohidráulica. $232 \mathrm{pp}$.

BALMFORD, A., A.BRUNER, P, COOPER, R. COSTANZA, S. FARBER, R. E. GREEN, M. JENKINS, P. JEFFERISS, V. JESSAMY, J. MADDEN, K. MUNRO, N. MYERS, S. NAEEM, J. PAAVOLA, M. RAYMENT, S. ROSENDO, J. ROUGHGARDEN, K. TRUMPER, R. K., TURNER, 2002. Economic reasons for conserving wild nature. Science, 297: 950-953.

BARBOUR, M. T., J. GERRITSEN, B. D. ZINDER \& J. B. STRIBLING. 1999. Rapid bioassessment protocols for use in streams and wadeable rivers: Periphyton, benthic macroinvertebrates and fish. $2^{\text {nd }}$ edition, EPA 841-B-99-002. Washington, D.C. $38 \mathrm{pp}$.

BENDA, L., N. L. POFF, D. MILLER, T. DUNNE, G. REEVES, G. PESS, \& D M. POLLOCK. 2004. The network dynamics hypothesis: How channel networks structure riverine habitats. BioScience, 54: 413-427.

BENDIX, J. \& C. R. HUPP 2000. Hydrological and geomorphological impact on riparian plant communities. Hydrological Processess, 14: 2977-2999.

BJORKLAND, R., C. M. PRINGLE \& B. NEWTON 2001. A stream visual assessment protocol (SVAP) for riparian landowners. Environmental Monitoring and Assessment, 68(2): 99-125.

BRIERLEY, G., K. FRYIRS, D. OUTHET \& C. MASSEY. 2002. Application of the River Styles framework as a basis for river management in New South Wales, Australia. Applied Geography, 22: 91-122.

BRIERLEY, G. J. \& K. A. FRYIRS. 2005. Geomorphology and River Management. Applications of the River Styles Framework. Blackwell Publishing, Victoria, Australia. 389 pp.

BURT, T., M. M. HEFTING, G. PINAY \& S. SABATER. 2006. The role of floodplains in mitigating diffuse nitrate pollution. In: Hydroecology and 
Ecohydrology: Past, Present and Future P. Wood, D. M. Hannah \& J. P. Sadler (eds.): 253-268. John Wiley \& sons, Chichester, UK.

CALABRESE, J. M. \& W. F. FAGAN. 2004. A comparison shopper's guide to connectivity metrics. Front Ecol Environ, 2(10): 529-536.

CORENBLIT, D., E. TABACCHI, J. STEIGER \& A. M. GURNELL 2007. Reciprocal interactions and adjustments between fluvial landforms and vegetation dynamics in river corridors: A review of complementary approaches. Earth-Science Reviews, 84: 56-86.

CORENBLIT, D., A. M. GURNELL, J. STEIGER \& E. TABACCHI. 2008. Reciprocal adjustments between landforms and living organisms: Extended geomorphic evolutionary insights. Catena, 73: 261273.

CORENBLIT, D., J. STEIGER, A. M. GURNELL \& R. J.NAIMAN. 2009. Plants interwine fluvial landform dynamics with ecological succession and natural selection: A niche construction perspective for riparian systems. Global Ecology and Biogeography, 18: 507-520.

DAVIES, N. M., R. H. NORRIS \& M. C. THOMS. 2000. Prediction and assessment of local stream habitat features using large-scale catchment characteristics. Freshwater Biology, 45: 343-369.

DUNNE, T. \& L. B. LEOPOLD. 1978. Water in Environmental Planning. V. H. Freeman \& Co., San Francisco, USA. 818 pp.

ESTRELA, T. 1994. Aspectos prácticos de la definición de la máxima crecida ordinaria. Informe Asistencia Técnica para la ordenación de cauces y márgenes inundables. CEDEX 42-493-6-001. Madrid. 49 pp.

FEDERAL INTERAGENCY STREAM CORRIDOR RESTORATION WORKING GROUP(FISRWG). 1998. Stream Corridor Restoration. Principles, processes, and practices. U.S. National Engineering Handbook, Part 653, Washington, D.C.: USDA, Natural Resources Conservation Service. $528 \mathrm{pp}$.

FORMAN, R. T. T. 1999. Land Mosaics. The ecology of landscapes and regions. Cambridge University Press, Cambridge, UK. 632 pp.

FRANCÉS, F., F. MARTÍNEZ-CAPEL, V. GARÓFANO-GÓMEZ, A. GARCÍA-ARIAS, M. MORALES DE LA CRUZ, J. REAL-LLANDERAL R. COSTA, J. F. VILLANUEVA-GARCÍA, J. L. GARCÍA-GALLÉN, \& R. MUÑOZ-MAS. 2009. Proyecto RIBERA: Modelación matemática de ecosistemas de ribera para la determinación de regímenes ecológicos en el río. Technical Report of the Universidad Politécnica de Valencia for the Spanish Government (MARM). 425 pp.

GONZÁLEZ DEL TÁNAGO, M., D. GARCÍA DE JALÓN \& R. MARTINEZ. 2004. Caracterización geomorfológica de la red fluvial del Alto y Medio Guadiana. Technical Report, CEDEX, Madrid. $115 \mathrm{pp}$.

GONZÁLEZ DEL TÁNAGO, M., D. GARCÍA DE JALÓN, F. LARA \& R. GARILLETI. 2006. Índice RQI para la valoración de las riberas fluviales en el contexto de la Directiva Marco del Agua. Ingeniería Civil, 143: 97-108.

GONZÁLEZ DEL TÁNAGO, M. \& D. GARCÍA DE JALÓN. 2006 Attributes for assessing the environmental quality of riparian zones. Limnetica, 25(12): 389-402.

GOODWIN, B. J. 2003. Is landscape connectivity a dependent or independent variable? Landscape Ecology, 18: 687-699.

GURNELL, A. M. \& G. E. PETTS. 2002. Islanddominated landscapes of large floodplain rivers. A European perspective. Freshwater Biology, 47: 581-600.

GURNELL, A. M. \& G. E. PETTS. 2006. Trees as riparian engineers: the Tagliamento River, Italy. Earth Surface Processes and Landforms, 31: 15581574.

HORN, R. P. \& J. S. RICHARDS. 2006. Flow-vegetation interactions in restored floodplain environments. In: Hydroecology and Ecohydrology: Past, Present and Future. P. Wood, D. M. Hannah \& J. P. Sadler (eds.): 269-294. John Wiley \& sons, Chichester, UK.

HUGHES, F. M. R. (ed.) 2003. The Flooded Forest: Guidance for policy makers and river managers in Europe on the restoration of floodplain forests. FLOBAR2, Department of Geography, University of Cambridge, UK. 96 pp.

HUGHES, F. M. R. \& S. B. ROOD. (2003). The allocation of river flows for the restoration of woody riparian and floodplain forest ecosystems: a review of approaches and their application in Europe. Environmental Management, 32: 12-33.

HUPP, C. R. \& M. RINALDI. 2007. Riparian Vegetation Patterns in Relation to Fluvial Landforms and Channel Evolution Along Selected Rivers of Tuscany (Central Italy). Annales of the Association of American Geographers, 97(1): 12-30. 
ITURRIAGA, C. 2007. Evaluación del estado hidromorlógico de los ríos de Navarra y caracterización de sus formaciones riparias. Trabajo Fin de Carrera, E.T.S. I. Montes, UPM, Madrid. 153 pp.

JANSEN, A., A. ROBERTSON, L. THOMPSON \& A. WILSON. 2004. Development and application of a method for the rapid appraisal of riparian condition. River and Riparian Land Management Technical Guideline, 4. Land \& Water Australia, Camberra. 14 pp.

LADSON, A. R. \& L. J. WHITE. 2000. Measuring stream condition. In: River Management. The Australasian Experience. S. Brizga \& B. Finlayson (eds.): 265-285. John Wiley \& sons, Chichester. UK.

MALANSON, G. P. 1993.Riparian Landscapes. Cambridge University Press, Cambridge, UK, 296 pp.

MUNNÉ, A., C. SOLÁ \& N. PRAT. 1998. QBR : Un índice rápido para la evaluación de la calidad de los ecosistemas de ribera. Tecnología del Agua, 175: 20-37.

MUNNÉ, A., N. PRAT, C. SOLÁ, N. BONADA \& M. RIERADEVALL. 2003. A simple field method for assessing the ecological quality of riparian habitat in rivers and streams: QBR index. Aquatic Conservation: Marine and Freshwater Ecosystems, 13: 143-162.

NAIMAN, R. J., H. DÉCAMPS \& M. E. McCLAIN. 2005. Riparia. Ecology, Conservation and Manament of Streamside Communities. Elsevier Academic Press, Amsterdam, 430 pp.

NILSSON, C. H. \& K. BERGGREN. 2000. Alterations of Riparian Ecosystems caused by River Regulation. BioScience, 50(9): 783-792.

OJEC (Official Journal of the European Communities). 2000. Directive 2000/60/EC of the European Parliament and of the Council of 23 October 2000 establishing a framework for Community action in the field of water policy.

OJEU (Official Journal of the European Union) 2007. Directive 2007/60/EC of the European Parliament and of the Council of 26 November 2007 on the assessment and management of flood risks.

OJEU (Official Journal of the European Union) 2009. Directive 2009/128/EC of the European Parliament and of the Council of 21 October 2009 establishing a framework for Community action to achieve the sustainable use of pesticides.

OLLERO, A., D. BALLARIN, E. DIAZ, D. MORA, M. SANCHEZ, V. ACIN, T. ECHEVARRIA, D. GRANADO, A. IBISATE, L. SANCHEZ \& N.
SANCHEZ. 2008. IHG: An index for the hydrogeomorphological assessment of fluvial systems. Limnetica, 27: 171-187.

OLLERO, A., L. E. GONZALO, A. IBISATE, V. ACIN, D. BALLARÍN, E. DIAZ, S. DOMENECH, M. GIMENO, D. GRANADO, J. HORACIO, D. MORA \& M. SANCHEZ. 2011. The IHG Index for hydromorphological quality assessment of rivers: Updated version, working methodology and applications. Limnetica, 30(2): 255-262.

PARDO, I., M. ALVAREZ, J. CASAS, J. L. MORENO, S. VIVAS, N. BONADA, J. ALBA-TERCEDOR, P. JAIMEZ-CUELLAR, G. MOYA, N. PRAT, S. ROBLES, M. L. SUÁREZ, M. TORO \& M. R. VIDAL-ABARCA. 2002. El hábitat de los ríos mediterráneos. Diseño de un índice de diversidad de hábitat. Limnetica, 21: 115-133.

PETERSEN, R. 1992. The RCE: A riparian, channel and Environmental Inventory for small streams in the agricultural landscape. Freshwater Biology, 27: 295-306.

POOLE, G. C. 2002. Fluvial landscape ecology: addressing uniqueness within the river discontinuu. Freshwater Biology, 47: 641-660.

RAVEN, P. J., P. FOX, M. EVERARD, N. T. H. HOLMES \& F. H. DAWSON. 1997. River Habitat Survey: a new system for classifying rivers according to their habitat quality. In: Freshwater Quality: Defining the Indefinable? P. J. Boon \& D. L. Howell (eds.): 215-234. The Stationary Office, Edinburg.

SCHNITZLER-LENOBLE, A. 2007. Fôrets alluviales d'Europe. Écologie, Biogéographie and Valeur intrinsèque. Lavoisier, Ed. Tec \& Doc, París. 387 pp.

SIMPSON, J. C. \& R. H. NORRIS. 2000. Biological Assessment of river quality: development of AUSRIVAS models and outputs. In: Assessing the biological quality of freshwaters. RIVPACS and other techniques J. F. Wright, D. W. Sutcliffe \& M. T. Furse, M.T. (eds.): 115-142. Freshwater Biological Association, Ambleside.

TABACCHI, E., L. LAMBS, H. GUILLOY, A. M. H. PLANTY-TABACCHI, E. MULLER \& H. DÉCAMPS. 2000. Impacts of riparian vegetation on hydrological processes. Hydrological Processes, 14: 2959-2976.

TOCKNER, K. \& J. A. STANFORD 2002. Riverine flood plains: present state and future trends. Environmental Conservation, 29(3): 308-330. 
WARD, J. V. 1989. The four-dimensional nature of lotic ecosystems. Journal of the North American Benthological Society, 8: 2-8.

WARD, J. V., K. TOCKNER D. B. ARSCOTT \& C. Claret. 2002. Riverine landscape diversity. Freshwater Biology, 47: 517-539.

WARD, T. A., K. W. TATE \& E. R. ATWILL. 2003. Visual assessment of riparian health. Rangeland
Monitoring Series, ANR Publication 8089, Regents of the University of California, Division of Agriculture and Natural Resources, Oakland, California. 23 pp.

WINWARD, A. H. 2000. Monitoring the Vegetation Resources in Riparian Areas. USDA Forest Service, General Technical Report RMRS-GTR-47, Ogden, Utah. 49 pp. 


\section{ANNEX I \\ FIELD DATA SHEET FOR CHARACTERIZING AND ASSESSING RIPARIAN CONDITIONS}

River:

Code station:

Date:

Observer:

Limits of River segment:

GPS beginning

GPS end:

Valley and channel cross-section:

\begin{tabular}{|l|c|c|}
\hline 1. Dimensions of Land with Riparian Vegetation & Right margin & Left margin \\
\hline Confinement of margin (C: confined; U: unconfined) & & \\
\hline Maximum/Minimum width with riparian vegetation (m) & $/$ & \\
\hline Average width of riparian corridor (m) & & \\
\hline Average width of active channel (m) & & \\
\hline Distance between active channel bank and adjacent up-slope (m) & & \\
\hline Adjacent land use (Forest, Agriculture, Urban area, Roads, Others) & & \\
\hline \multicolumn{1}{|c|}{ SCORE: } & & \\
\hline
\end{tabular}

\begin{tabular}{|l|l|l|}
\hline 2. Longitudinal Continuity and Coverage of Riparian Corridor & Right margin & Left margin \\
\hline Continuous forest (CF) / Vegetation Patches (VP) / Isolated trees or shrubs (IT, IS) & & \\
\hline Canopy ( $>5 \mathrm{~m}$ height) cover $(\%)$ & & \\
\hline Understory (1-5 m height) cover (\%) & & \\
\hline Ground (<1 m height) cover $(\%)$ & & \\
\hline If fragmented, average vegetation patches length (m) & & \\
\hline If fragmented, average distance between consecutive patches (m) & & \\
\hline If fragmented, land use in open areas & & \\
\hline & & \\
\hline
\end{tabular}

\begin{tabular}{|l|l|l|}
\hline 3. Composition and Structure of Riparian vegetation & Right margin & Left margin \\
\hline Predominant vegetation associations & & \\
\hline Tree species: Name and abundance class & & \\
\hline Shrub species: Name and abundance class & & \\
\hline Ground species: Name and abundance class & & \\
\hline Shadow and climbing plants: Name and abundance class & & \\
\hline Exotic woody species: Name and cover (\%) & & \\
\hline Coverage of Rubus or reeds (\%) & & \\
\hline Coverage of ruderal or invasive herbaceous species (\%) & & \\
\hline Coverage of Arundo donax (\%) & & \\
\hline Health status of main native woody species (Good, Fair, Bad) & & \\
\hline
\end{tabular}

Abundance classes: 4: Dominant; 3: Abundant; 2: Frequent; 1: Scarce; + Occasional 


\begin{tabular}{|c|c|}
\hline 4. Age diversity and Natural Regeneration & Both margins \\
\hline Species with seedlings ( $<1$ year, $<0.25 \mathrm{~m}$ height) & \\
\hline Species with youngs (aprox. $0.25-1.0 \mathrm{~m}$ height, or $<1.5 \mathrm{~cm}$ diameter for trees) & \\
\hline Species with adults (aprox. 1.0-5.0 m height, $1.5-3 \mathrm{~cm}$ diameter for trees) & \\
\hline Species with mature (aprox. $>5.0 \mathrm{~m}$ height, $>3 \mathrm{~cm}$ diameter for trees) & \\
\hline Species with dead trees: Name and abundance class & \\
\hline Regeneration sites: Channel banks, Proximal area, Distal area, Total area & \\
\hline $\begin{array}{l}\text { Regeneration prevented by: Flow regulation / Cattle grazing / Ploughing / Herbicides / Soil } \\
\text { compaction / Pavement / Others }\end{array}$ & \\
\hline SCORE: & \\
\hline
\end{tabular}

\begin{tabular}{|c|c|}
\hline 5. Bank conditions & Both margins \\
\hline Bank material (Bedrock, Gravel, Sand, Fine sediments, Composite strata) & \\
\hline $\begin{array}{l}\text { Bank shape (Natural, Reprofiled, Reveted, Embanked, Concreted, Other) } \\
\text { Draw a simplified profile }\end{array}$ & \\
\hline Banktop height (m) & \\
\hline Bankside slope (Uniform (V:H) / Composite (V:H) & \\
\hline Bank vegetation cover (\%) & \\
\hline Dead wood and vegetation debris (Abundant, Present, Occasional, Absent) & \\
\hline Bank stability (Stable, with local instability, Unstable) & \\
\hline Channel processes description: Equilibrium, Narrowing, Widening & \\
\hline Bank length affected by vertical accretion/incision (\%) & \\
\hline Bank length affected by undecutting/mass failure (\%) & \\
\hline Bank length with revetments/bio-engineering (\%) & \\
\hline SCORE: & \\
\hline
\end{tabular}

\begin{tabular}{|c|c|}
\hline 6. Floods and Lateral Connectivity & Both margins \\
\hline \multicolumn{2}{|l|}{ Flow regime status (Natural, Regulated: Slightly, Moderately, Significantly) } \\
\hline \multicolumn{2}{|l|}{ If regulated, main purposes (Irrigation, Hydroelectricity, Water supply) } \\
\hline \multicolumn{2}{|l|}{ Annual floods timing (natural conditions, only in summer, at any time) } \\
\hline \multicolumn{2}{|l|}{ Restrictions to riparian flood access (Bank elevation, channel deepening, levees ) } \\
\hline \multicolumn{2}{|l|}{ Embankments: Height (m)/Distance from active channel bank (m) } \\
\hline \multicolumn{2}{|l|}{ Estimated frequency of banktop overflows (one each 1-2 y, $5 \mathrm{y}, 10 \mathrm{y}, 25 \mathrm{y},>25 \mathrm{y}$ ) } \\
\hline \multicolumn{2}{|l|}{ Estimated frequency of proximal riparian area flooding (one each 1-2 y, 5 y, $10 \mathrm{y}, 25 \mathrm{y},>25 \mathrm{y}$ ) } \\
\hline \multicolumn{2}{|l|}{ Estimated frequency of distal riparian area flooding (one each 1-2 y, 5 y, 10 y, 25 y, > 25 y) } \\
\hline \multicolumn{2}{|l|}{$\begin{array}{l}\text { Abundance of dead wood and woody branches transported by floods (None, Occasional, Abundant, } \\
\text { Very abundant) }\end{array}$} \\
\hline \multicolumn{2}{|l|}{$\begin{array}{l}\text { Location of dead wood and woody branches transported by floods (Only at banks, In proximal } \\
\text { riparian areas, In distal areas, everywhere) }\end{array}$} \\
\hline $\begin{array}{lc} & \text { SCORE: }\end{array}$ & \\
\hline
\end{tabular}

\begin{tabular}{|l|l|}
\hline 7. Substratum and Vertical Connectivity & Both margins \\
\hline Predominant soil surface cover (rocks, wood, leaf litter, grass, bare soil, others) & \\
\hline Coverage of vegetation detritus and grass (\%) & \\
\hline Coverage of bare soil compacted or paved (\%) & \\
\hline Intensity of cattle grazing (None, not significant, moderate, intense, very intense) & \\
\hline Herbaceous communities (Natural, Abundant /Dominant opportunistic species) & \\
\hline$\%$ of area affected by gravel mining or excavations & \\
\hline$\%$ of area affected by sediment fillings & \\
\hline$\%$ of area affected by solid wastes and building debris & \\
\hline Present underground infrastructures (None, Pipes, roads, buildings, others) (\% area affected) & SCORE: \\
\hline \multicolumn{2}{|c|}{} \\
\hline
\end{tabular}


